\title{
SISTEM DETEKSI PETIR MULTISTATION DENGAN METODE TIME OF ARRIVAL
}

\author{
Dasrinal Tessal $^{1}$, Primas Emeraldi², Ariadi Hazmi ${ }^{2}$ \\ ${ }^{1}$ Mahasiswa S2 Teknik Elektro, Universitas Andalas \\ ${ }^{2}$ Jurusan Teknik Elektro, Universitas Andalas \\ e-mail: das_04e14@yahoo.co.id
}

\begin{abstract}
Abstrak-Penelitian ini dilakukan pada sistem deteksi petir yang dibangun di kota Padang. Sistem terdiri dari 3 sensor medan listrik dan GPS yang tersinkronisasi. Perbedaan waktu datang dan koordinat sensor didapatkan dari masing-masing sensor. Data ini digunakan untuk mendapatkan lokasi kejadian petir dengan metode Time of Arrival Linear Spherical. Setelah lokasi petir didapatkan maka jarak antara stasiun dengan lokasi kejadian petir dapat diketahui. Jarak sensor dengan petir dibandingkan dengan parameter gelombang medan listrik yang terekam sehingga dapat diketahui validnya hasil perhitungan. Setelah hasil perhitungan valid maka arus puncak dapat ditentukan. Dari 20 data tersebut terdapat 8 data yang bentuk gelombang medan listriknya sesuai dengan jarak antara sensor dengan lokasi petir dengan arus puncak petir yang terendah berada pada nilai -1,001 kA dan tertinggi berada pada nilai -22,661 kA.
\end{abstract}

Kata Kunci : Petir, Sistem Deteksi Petir, Time of Arrival, Arus Puncak Petir.

\begin{abstract}
This study was done at ligtning detection system in Padang. The systems was consist of 3 electric field sensors with synchronous satelite GPS. Time of arrival and sensors coordinate was taken from each sensors. This data was used to calculate ligtning location by Time of Arrival Linear Spherical method. Then the distances between lighting and sensor can be calculated. The distances will compared with electric field waveforms recorded at lightning sensor to testing validity our results. After validity, lightning current peak can be calculated. 8 of 20 data sample are valid with lowest lightning current peak is $-1,001 \mathrm{kA}$ dan highest value is $-2,661 \mathrm{kA}$.
\end{abstract}

Keywords : Lightning, Lightning Detection System, Time of Arrival Ligtning Current Peak.

\section{PENDAHULUAN}

Petir adalah fenomena alam yang dapat menyebabkan berbagai macam kerusakan $[\mathbf{1 , 2}]$ Kematian bagi manusia, kerusakan jaringan kereta listrik, kerusakan pada pesawat terbang, jaringan telekomunikasi, serta jaringan listrik merupakan beberapa contoh dari kekuatan petir itu sendiri $[3,4]$.

Pendeteksian petir pada saat ini dibangun dengan menggunakan prinsip medan elektromagnetik [5]. Sistem pendeteksian petir di beberapa negara seperti EUCLID (Eropa), ALDIS(Austria), NLDN (Amerika Serikat), CLDN (Kanada), Blitzortung (Jerman), SAFIR/FLITS (Belanda), dan BrazilDat (Brazil) $[\mathbf{1 , 6 ]}$ merupakan contoh dari sistem deteksi petir yang menggunakan prinsip medan elektromagnetik.

Karakteristik penting sebuah sistem deteksi petir adalah akurasi lokasi [7]. Akurasi ini dipengaruhi oleh akurasi antena, lokasi antena, dan bentuk geometri sistem yang dipakai.
Pembuatan sistem deteksi petir di Sumatra Barat dengan metode Time of Arrival ini memerlukan evaluasi terhadap karakteristik penting ini. Akurasi lokasi petir berpengaruh pada data distribusi petir yang dihasilkan nantinya, dengan data distribusi petir tersebut dapat dipakai dalam merancang proteksi petir yang lebih baik [2].

Penentuan lokasi petir dapat dilakukan dengan menggunakan metode Time of Arrival. Beberapa metode Time of Arrival yang telah diterapkan pada beberapa sistem lokasi petir di dunia umumnya menggunakan rumus hiperbola yang diperbaiki dengan metoda numerik [8, 9]. Koshak dkk [10] menemukan sebuah metoda aljabar linear untuk menggantikan metode lama tersebut disebut dengan metode Time of Arrival Linear Spherical (ToA LS). Metode ini dapat digunakan secara luas dan tidak dipungut biaya.

Berdasarkan fakta-fakta tersebut penelitian ini menggunakan metode yang diperkenalkan Koshak dkk [10] dalam menentukan lokasi petir terhadap sistem deteksi petir yang dibangun pada daerah Kota Padang. Hasil perhitungan 
lokasi akan dibandingkan dengan karakteristik gelombang medan listrik petir berdasarkan jarak yang dikemukakan oleh Lin dkk [11]. Setelah validasi maka arus sebagai parameter kekuatan petir yang terjadi dapat kita tentukan.

\section{TINJAUAN PUSTAKA}

\subsection{Metoda Time of Arrival Linear Spherical} (ToA LS)

Metode ini dikembangkan Koshak dkk dengan memperhitungkan bentuk permukaan bumi yang melengkung yang diabaikan pada metode Linear Planar (LP) dan Quadratic Planar (QP) [10]. Metode ini menggunakan koordinat bola (Gambar 1), berbeda dari metode LP dan QP yang menggunakan koordinat kartesian sehingga tidak diperlukan transformasi dari koordinat kartesian ke bentuk koordinat bumi. Jika meridian utama merupakan bujur $\lambda=$ 0 , serta ekuator dengan lintang $\varphi=0$. Jika jarijari bumi disimbolkan dengan $r$, maka $\mathbf{r}=r \hat{\mathbf{r}}$ merupakan lokasi petir dan $\mathbf{r}_{\mathbf{i}}=r \hat{\mathbf{r}}_{\mathbf{i}}$ adalah lokasi sensor $i$, unit vektornya sebagai berikut :

$$
\begin{aligned}
& \widehat{\mathbf{r}}_{\mathbf{i}}=\cos \varphi_{i} \cos \lambda_{\mathrm{i}} \widehat{\mathbf{u}}+\cos \varphi_{\mathrm{i}} \sin \lambda_{\mathrm{i}} \hat{\mathbf{v}}+\sin \varphi_{\mathrm{i}} \widehat{\mathbf{w}}, \\
& \hat{\mathbf{r}}=\cos \varphi \cos \lambda \widehat{\mathbf{u}}+\cos \varphi \sin \lambda \hat{\mathbf{v}}+\sin \varphi \widehat{\mathbf{w}}
\end{aligned}
$$

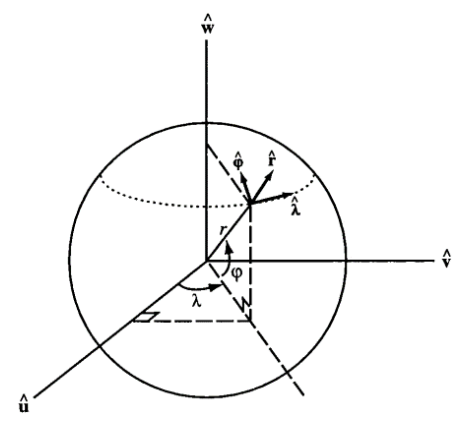

Gambar 1. Koordinat Bumi dalam Metode ToA LS [10]

Persamaan waktu deteksi dalam bentuk koordinat bumi adalah;

Jika terdapat 4 sensor atau lebih maka persamaan metode ToA LS adalah;

$$
t_{i}=t+\frac{1}{c} r \theta_{i}
$$

$\theta_{i}=\cos ^{-1}\left(K_{i 1} \cos \varphi \cos \lambda+K_{i 2} \cos \varphi \sin \lambda+K_{i 3} \sin \varphi\right)$

Dimana ;

$$
t=\text { waktu terjadinya petir pada } \mathbf{r}
$$

$t_{i}=$ waktu pengukuran kejadian pada $\mathbf{r}_{i}$

$\theta_{i}=$ sudut antara unit vektor persamaan 1

Menggunakan identitas trigonometri strandar maka persamaan 2 dapat ditulis ulang.

$$
\begin{aligned}
& \cos \frac{c}{r} t_{i} \cos \frac{c}{r} t+\sin \frac{c}{r} t_{i} \sin \frac{c}{r} t \\
& =K_{i 1} \cos \varphi \cos \lambda+K_{i 2} \cos \varphi \sin \lambda+K_{i 3} \sin \varphi
\end{aligned}
$$

Untuk mendapatkan solusi linear persamaan 3 dibagi dengan $\sin (c t / r)$ sehingga persamaan linearnya adalah ;

$$
\mathrm{g}_{i}=K_{i 1} f_{1}+K_{i 2} f_{2}+K_{i 3} f_{3}+K_{i 4} f_{4}
$$

dimana ;

$$
\begin{aligned}
\mathrm{g}_{i} & =\sin \left(\frac{c t_{i}}{r}\right) \\
f_{1} & =\cos \varphi \cos \lambda / \sin \left(\frac{c t}{r}\right) \\
f_{2} & =\cos \varphi \sin \lambda / \sin \left(\frac{c t}{r}\right) \\
f_{3} & =\sin \varphi / \sin \left(\frac{c t}{r}\right) \\
f_{4} & =\cot \left(\frac{c t}{r}\right) \\
K_{i 4} & =-\cos \left(\frac{c t_{i}}{r}\right)
\end{aligned}
$$

Persamaan 4 ditulis dalam bentuk matrik sebagai $\mathbf{g}=\mathbf{K} \mathbf{f}$ dengan solusi langsungnya $\mathbf{f}=\mathbf{K}^{\mathbf{- 1}} \mathbf{g}(n=$ 4), maka lokasi petir dan waktu terjadinya didapatkan dari matrik f sebagai berikut :

$\varphi=\tan ^{-1}\left(\frac{f_{3}}{f_{1}} \cos \lambda\right), \quad \lambda=\tan ^{-1}\left(\frac{f_{2}}{f_{1}}\right), \quad t=\frac{r}{c} \cot ^{-1} f_{4}$

Untuk standarisasi matrik, koordinat koordinat spasial di rotasi dan ditranslasikan ke koordinat sementara. Rotasi dilakukan dengan mengubah sistem koordinat $(\widehat{\mathbf{u}}, \widehat{\mathbf{v}}, \widehat{\mathbf{w}})$ menjadi $\left(\widehat{\mathbf{u}}^{\prime}, \widehat{\mathbf{v}}^{\prime}, \widehat{\mathbf{w}}^{\prime}\right)$ dengan sudut Euler $\lambda_{1}$ sebesar $\widehat{\mathbf{w}}$ dan $\left(\widehat{\mathbf{u}}^{\prime}, \widehat{\mathbf{v}}^{\prime}, \widehat{\mathbf{w}}^{\prime}\right)$ dirotasi dengan sudut Euler $\varphi_{1}$ sebesar - $\widehat{\mathbf{v}}^{\prime}$ menjadi $\left(\widehat{\mathbf{u}}^{*}, \widehat{\mathbf{v}}^{*}, \widehat{\mathbf{w}}^{*}\right)$ sehingga persamaannya dalam sistem bintang;

$$
\mathbf{a}=\mathbf{L h}
$$

dengan persamaan lengkapnya sebagai berikut ;

$$
a_{i-1}=L_{i-1,1} h_{1}+L_{i-1,2} h_{2}+L_{i-1,3} h_{3}(7)
$$


dimana ;

$$
\begin{aligned}
& a_{i-1}=\sin \left(\frac{c t_{i}}{r}\right) \\
& L_{i-1,1}=\cos \varphi_{i}^{*} \cos \lambda_{i}^{*}-\cos \left(\frac{c t_{i}}{r}\right) \\
& L_{i-1,2}=\cos \varphi_{i}^{*} \sin \lambda_{i}^{*} \\
& L_{i-1,3}=\sin \varphi_{i}^{*} \\
& h_{1}=\Psi^{*} \cos \varphi^{*} \cos \lambda^{*} \\
& h_{2}=\Psi^{*} \cos \varphi^{*} \sin \lambda^{*} \\
& h_{3}=\Psi^{*} \sin \varphi^{*} \\
& \Psi^{*}=-\left(1-\cos ^{2} \varphi^{*} \cos ^{2} \lambda^{*}\right)^{1 / 2}
\end{aligned}
$$

Tanda bintang $\left(^{*}\right)$ menandakan bahwa titik pusat koordinat berada pada stasiun 1 [12]

Maka Solusinya adalah ;

$$
\begin{array}{ll}
\mathbf{h}=\mathbf{L}^{-\mathbf{1}} \mathbf{a} & (n=4) \\
\mathbf{h}=(\tilde{\mathbf{L}} \mathbf{L})^{-\mathbf{1}} \tilde{\mathbf{L}} \mathbf{a} & (n>4)
\end{array}
$$

Maka lokasi petir sebagai berikut ;

$$
\begin{array}{r}
\varphi^{*}=\tan ^{-1}\left(\frac{h_{3}}{h_{1}} \cos \lambda^{*}\right), \\
\lambda^{*}=\tan ^{-1}\left(\frac{h_{2}}{h_{1}}\right)
\end{array}
$$

Lokasi asli petir dan $t_{l}$ adalah ;

$$
\begin{aligned}
& \varphi=\sin ^{-1}\left(K_{13} \cos \varphi^{*} \cos \lambda^{*}+\cos \varphi_{1} \sin \varphi^{*}\right), \\
& \lambda=\tan ^{-1}\left(\frac{K_{12} \cos \varphi^{*} \cos \lambda^{*}+\cos \lambda_{1} \cos \varphi^{*} \cos \lambda^{*}-K_{13} \sin \lambda_{1} \sin \varphi^{*}}{\left.K_{11} \cos \varphi^{*} \cos \lambda^{*}-\sin \lambda_{1} \cos \varphi^{*} \cos \lambda^{*}-K_{13} \sin \lambda_{1} \sin \varphi^{*}\right)}\right), \\
& T=T_{1}-\frac{r}{c} \cos ^{-1}\left(\cos \varphi^{*} \cos \lambda^{*}\right)
\end{aligned}
$$

\subsection{Perhitungan Jarak antara Dua Titik pada Permukaan Bumi}

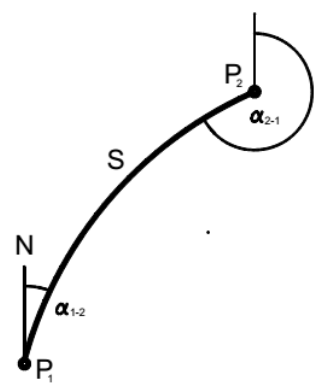

Gambar 2. Pencarian Jarak Antara Dua Koordinat pada Permukaan Bumi (Inverse Geodetic Problem) [13]
Perhitungan jarak antara dua koordinat titik dapat menggunakan Inverse Geodetic Problem (IGP) yang diperkenalkan oleh Sodano [13]. Dari dua koordinat yang diberikan yakni $\varphi_{1}, \lambda_{1}$ yang merupakan titik awal geodesic $\left(\mathrm{P}_{1)}\right.$ dan $\varphi_{2}$, $\lambda_{2}$ yang merupakan titik akhir $\left(\mathrm{P}_{2}\right)$ maka kita dapat mencari jarak $\mathrm{S}$ pada gambar 2.

$\operatorname{Jarak}(\mathrm{S})$ dapat dicari dengan persamaan berikut;

$S=A_{s} \Phi+B_{S}\left[c^{2} \Phi+(2 a-m \cos \Phi) \sin \Phi\right]$

dengan :

$$
\begin{aligned}
A_{s}=\left(a_{0}+b_{0}\right) / 2 \text { dan } B_{s}=\left(a_{0}-b_{0}\right) / 2 \\
\left(\mathrm{~b}_{0}=6378.137 \mathrm{~km}, \mathrm{a}_{0}=6356.752 \mathrm{~km}\right) \\
f \quad=1-\mathrm{b}_{0} / \mathrm{a}_{0}, \\
\tan \beta_{1}=(1-f) \tan \varphi_{1}, \\
\tan \beta_{2}=(1-f) \tan \varphi_{2} \\
a=\sin \beta_{1} \sin \beta_{2}, \quad b=\cos \beta_{1} \cos \beta_{2} \\
L \quad=\lambda_{2}-\lambda_{1}
\end{aligned}
$$

$\cos \Phi=a+b \cos L$

$$
\begin{aligned}
& c=\frac{b \sin L}{\sin \Phi} \\
& m=1-c^{2}
\end{aligned}
$$

\subsection{Perkiraan Arus Puncak Petir}

Menurut Uman arus puncak petir didapatkan dari model saluran transmisi [14] .Arus puncak ini berkaitan dengan puncak Medan Elektrik (Ep) yang dirumuskan sebagai berikut ;

$$
I_{p}=\frac{2 \cdot \pi \cdot \varepsilon_{0} \cdot c^{2} D}{v} E_{p}
$$

dimana :

$\mathrm{D}=$ jarak horizontal antara petir dan titik pengamatan

$\mathrm{v}=\left(1,8 \times 10^{8} \mathrm{~m} / \mathrm{s}\right)$ kecepatan sambaran balik

$\mathrm{c}=$ kecepatan cahaya $\left(3 \times 10^{8} \mathrm{~m} / \mathrm{s}\right)$

$E p=$ nilai puncak medan listrik

$\varepsilon_{0}=\left(8,854 \times 10^{-12}\right)$ 
Sedangkan Ep sendiri didapatkan dari persamaan berikut ;

$$
E=\frac{V_{d} C}{G A \varepsilon_{0}}
$$

dimana :

$$
\begin{aligned}
V_{d}= & \text { tegangan yang terbaca oleh perekam } \\
& \text { digital (Picoscope) } \\
\mathrm{C}= & \text { kapasitansi integrator } \\
\mathrm{G}= & \text { Gain(Penguatan keseluruhan sistem) } \\
\mathrm{A}= & \text { luas plat antena } \\
\varepsilon_{0}= & \text { permivitas ruang hampa } \\
& \left(8,854 \times 10^{-12}\right)
\end{aligned}
$$

\subsection{Bentuk Gelombang Petir Berdasarkan dengan Jarak dan Arus}

Bentuk gelombang petir dapat dijadikan acuan dalam melihat jarak dan arus petir yang ditangkap oleh sensor petir. Lin dkk [11] telah mengelompokkan bentuk gelombang berdasarkan jarak 1 sampai $200 \mathrm{~km}$ yang dilakukan pada sensor petir di Florida. Pengelompokkan bentuk gelombang tersebut dapat dilihat pada gambar 3 .
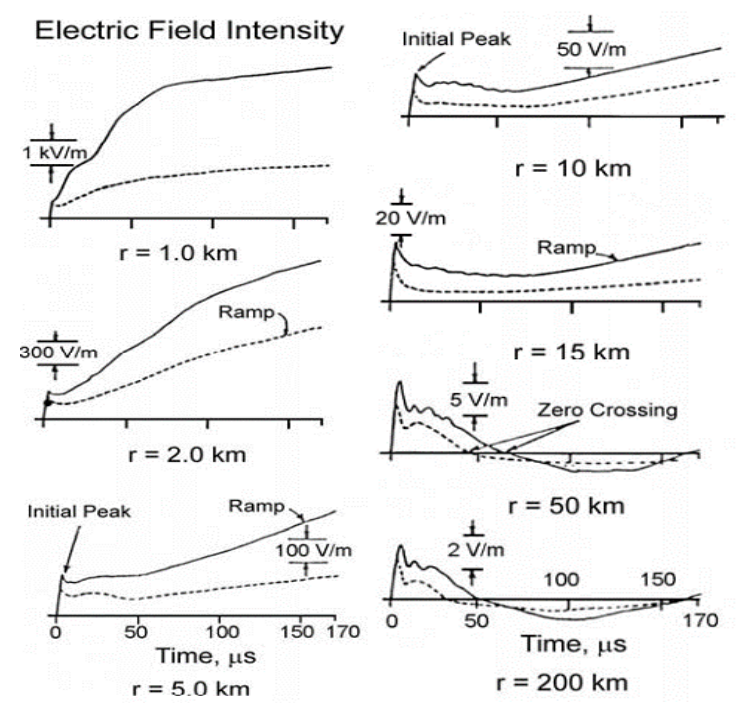

Gambar 3. Tipikal Karakteristik Bentuk Gelombang Petir berdasarkan Jarak [11]

\section{METODOLOGI PENELITIAN}

Sinyal petir ditangkap dengan antena medan listrik dengan skematik sensor petir seperti pada gambar 4. Data yang terekam akan diolah dengan program yang dibuat dengan bahasa pemograman Visual Basic 2010 hal ini dilakukan untuk memudahkan pencarian $\Delta t$ yang akan digunakan untuk perhitungan ToA LS dan menghitung jarak antara petir dengan sensor.

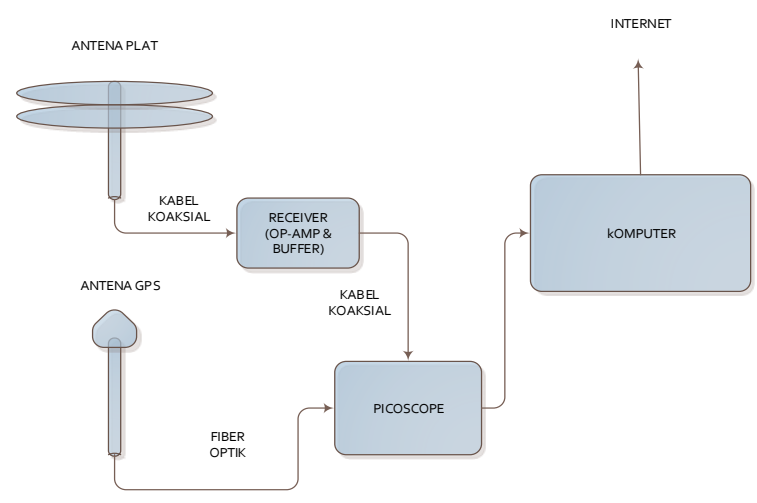

Gambar 4. Skema Sensor Petir

Sensor petir yang dipakai dalam penelitian ini berada pada lokasi yang diperlihatkan pada Tabel 1.

Tabel 1. Koordinat Stasiun Sensor Petir

\begin{tabular}{l|cc}
\hline \multicolumn{1}{c}{ Lokasi } & Lintang & Bujur \\
\hline Stasiun Tabing & -0.86977 & 100.33688 \\
Stasiun Padang Pasir & -0.93612 & 100.35688 \\
Stasiun Unand & -0.91372 & 100.46413 \\
\hline
\end{tabular}

Lokasi stasiun deteksi petir yang terpasang dapat dilihat pada Google Maps pada gambar 5.

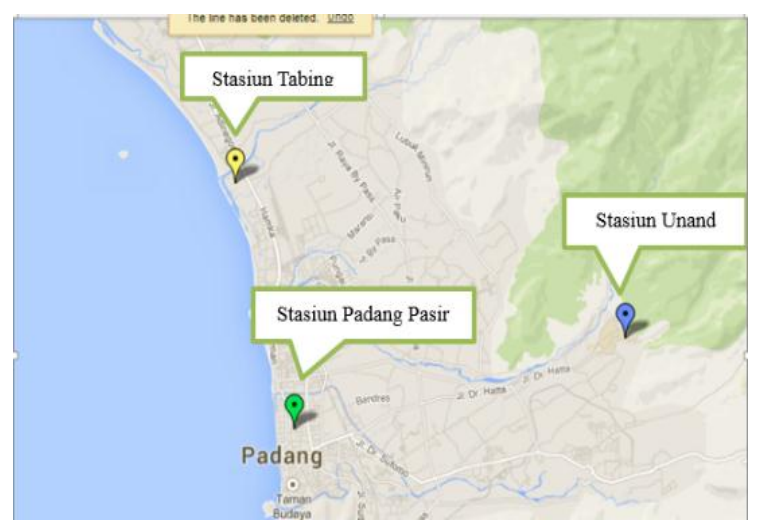

Gambar 5. Visualisasi Lokasi Koordinat Stasiun

Sinyal petir ditangkap dengan antena dan diperkuat dengan integrator op-amp. Sinyal analog akan diubah dalam bentuk digital dengan menggunakan perangkat Picoscope. Data digital 
akan memiliki waktu perekaman dan bentuk sinyal yang terekam. Data ini juga termasuk pulsa GPS (Global Positioning System) yang menjadi acuan dalam menentukan data $\Delta t$ pada setiap kejadian sambaran petir. Nilai $\Delta t$ didapatkan dari perbedaan perbedaan antara waktu pulsa naik dan waktu nol perekaman data, penentuan nilai $\Delta t$ pada satu stasiun yang dipakai dapat dilihat pada gambar 6 .



Gambar 6. Penentuan data nilai $\Delta t$

Data perekaman dari 3 stasiun dikumpulkan dan akan dipilah sesuai hari dan waktu yang sama. Pemilahan ini dilakukan oleh program yang dibuat dengan menggunakan Visual Basic 2010. Diagram alir program metode ToA LS dapat dilihat pada gambar 7 .

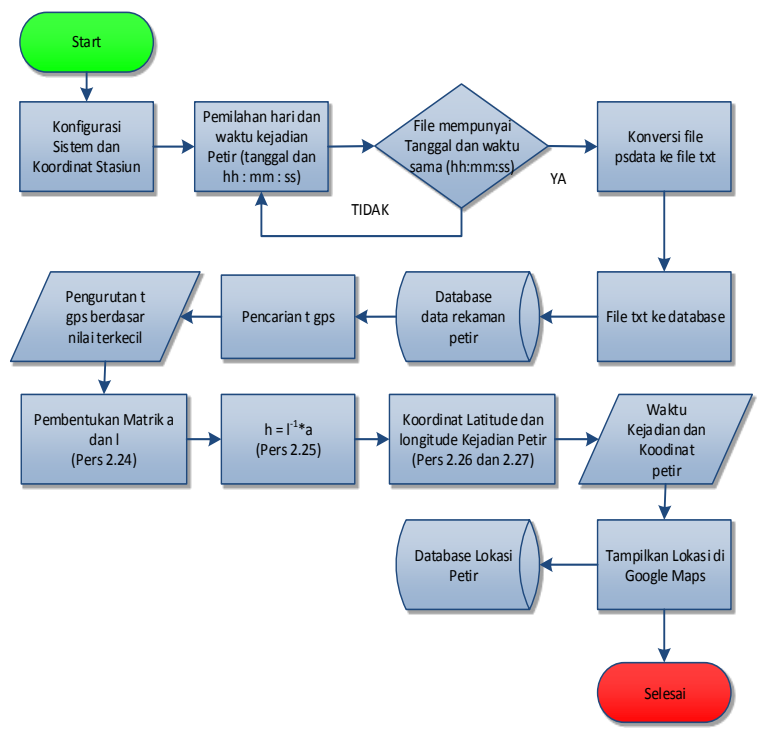

Gambar 7. Diagram Alir Utama Pengolahan Data

Data awal yang diperlukan adalah koordinat sistem. Data ini didapatkan dari perangkat lunak
GPS yang ada pada tiap stasiun petir. Data lainnya adalah $\Delta t$ tiap stasiun. Data ketiga stasiun ini dikumpulkan pada satu unit komputer untuk dilakukan pemilahan berdasarkan waktu dan tanggal kejadian. Kemudian pencarian lokasi petir dengan metode Toa LS. Setelah data koordinat petir di dapatkan melalui perhitungan program, lokasi petir ditampilkan pada aplikasi Google Maps. Jarak lokasi petir dengan stasiun dibandingkan dengan karakteristik bentuk sinyal gelombang medan listrik petir. Setelah memastikan lokasi petir sudah sesuai dengan karakteristik gelombang medan listriknya maka arus puncak petir dapat ditentukan.

\section{HASIL DAN PEMBAHASAN}

\subsection{Penerapan Metode ToA LS pada Sistem Sensor Petir}

Sistem berbentuk segitiga dengan pemilihan lokasi titik referensi nol diletakkan pada koordinat $-0.98134 \mathrm{LS}$ dan 100.37511 BB. Ini dilakukan untuk memenuhi syarat metode ToA LS dengan bentuk geometri segiempat [7]. Data diambil pada tanggal 12 Januari 2014 dengan sampel data sebanyak 20 data pada masingmasing stasiun dimana syarat waktu untuk metode ToA LS terpenuhi. Perhitungan jarak dilakukan dengan mengambil lokasi sensor Unand sebagai titik awal dan lokasi petir sebagai titik akhir. Maka dengan perhitungan program hasilnya dapat dilihat pada tabel 2 .

Tabel 2. Hasil perhitungan Program ToA LS

\begin{tabular}{c|cccc} 
No & Waktu & Lat & Long & $\begin{array}{c}\text { Jarak } \\
(\mathrm{km})\end{array}$ \\
\hline 1 & $14: 36: 57$ & $-0,88311$ & 100,40337 & 7,670 \\
2 & $14: 41: 50$ & $-0,53370$ & 100,33129 & 44,621 \\
3 & $14: 42: 55$ & $-0,88642$ & 100,40330 & 7,518 \\
4 & $14: 48: 26$ & $-0,88655$ & 100,40283 & 7,561 \\
5 & $16: 35: 10$ & $-0,88481$ & 100,40304 & 7,620 \\
6 & $17: 59: 00$ & $-0,88122$ & 100,41097 & 7,029 \\
7 & $18: 01: 21$ & $-0,84584$ & 100,51712 & 9,521 \\
8 & $18: 02: 54$ & $-0,88344$ & 100,40330 & 7,659 \\
9 & $18: 05: 24$ & $-0,86600$ & 100,45875 & 5,366 \\
10 & $18: 08: 33$ & $-0,97453$ & 100,44369 & 7,089 \\
11 & $18: 50: 38$ & $-0,73904$ & 100,37015 & 22,051 \\
12 & $18: 51: 58$ & $-0,99644$ & 100,36523 & 14,359 \\
13 & $18: 56: 20$ & $-0,77350$ & 100,38044 & 18,176 \\
14 & $19: 09: 08$ & $-0,88419$ & 100,40427 & 7,526 \\
15 & $19: 18: 46$ & $-0,88674$ & 100,40366 & 7,468 \\
16 & $21: 42: 59$ & $-0,88403$ & 100,40352 & 7,609 \\
17 & $21: 54: 34$ & $-0,75864$ & 100,44675 & 17,312 \\
18 & $21: 56: 59$ & $-0,88677$ & 100,40356 & 7,477 \\
19 & $21: 58: 00$ & $-0,74406$ & 100,37476 & 21,319 \\
20 & $22: 03: 06$ & $-0,81981$ & 100,39051 & 13,323 \\
\hline & & & & \\
\hline
\end{tabular}


Peta sebaran kejadian petir tersebut dapat dilihat pada Gambar 8 .

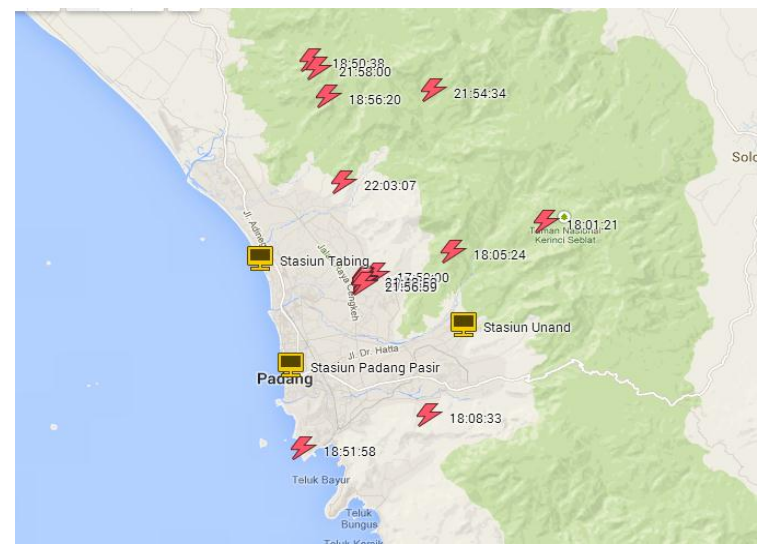

\section{Gambar 8. Peta Sebaran Kejadian Petir 12} Januari 2014

Pada gambar 8 kejadian petir dapat dibedakan atas 2 wilayah yakni kejadian petir yang terjadi didalam geometri sistem deteksi petir dan kejadian yang terjadi di luar lingkup geometri sistem. Petir yang terjadi pada geometri sistem deteksi petir terjadi pada 15 sampel.

Data 1 terjadi perbedaan antara jarak terhitung dengan $\Delta t$ yang didapatkan pada masing-masing stasiun, $\Delta t$ terkecil didapatkan oleh stasiun Unand namun lokasi petir malah dekat ke stasiun Tabing seperti yang ditampilkan pada gambar 9.



Gambar 9. Lokasi sampel petir pada waktu $14: 36: 57$

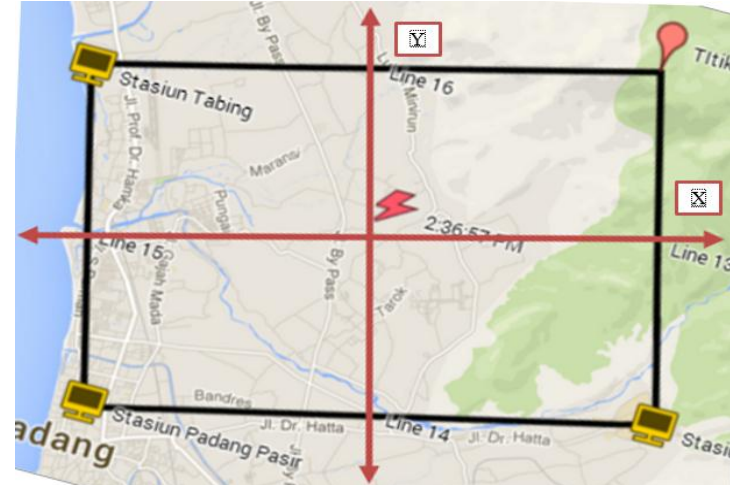

Gambar 10. Sumbu simetris pada geometri sistem deteksi petir

Penyimpangan jarak ini disebabkan lokasi petir dekat dengan sumbu geometri sistem sehingga munculnya galat dalam perhitungan. Galat yang dijelaskan oleh Koshak [15] sebagai "blind" pada sumbu simetris, dimana invers matrik a akan bernilai besar akibat nilai eigen matrik a menuju nol sehingga galat perhitungan akan semakin besar pula, hal inilah yang menyebabkan perhitungan jarak ketiga stasiun menjadi tidak sesuai dengan pengukuran $\Delta t$. Galat ini juga akan terjadi pada jika petir terjadi jika mendekati sumbu $\mathrm{x}$ atau y. Gambar 10 memperlihatkan bahwa data 1 terletak pada sumbu y sehingga terjadi perbedaan jarak dengan stasiun.

Perbandingan dengan bentuk gelombang yang terekam akan menentukan betul atau tidaknya lokasi yang didapatkan. Bentuk gelombang medan listrik pada data 1 dapat dilihat pada gambar 11. Bentuk gelombang ini sebelumnya sudah dikelompokkan berdasarkan oleh Lin dkk $[11,16]$ sehingga dapat menjadi acuan dalam menentukan lokasi petir yang didapatkan.

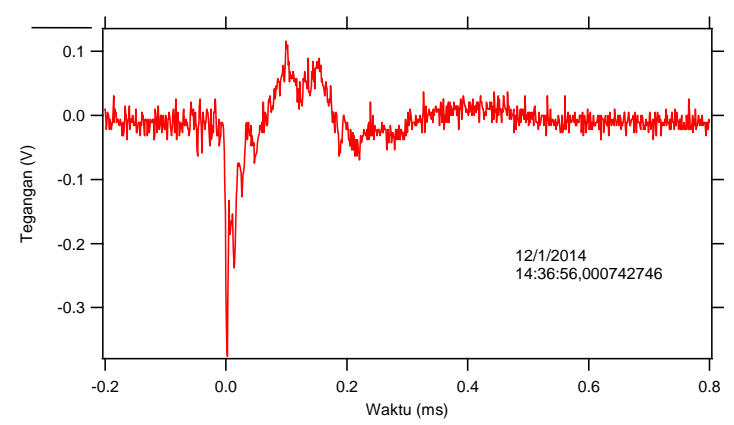

Gambar 11. Bentuk Gelombang Medan Listrik Petir pada Data 1(14:36:56) 
Bentuk gelombang medan listrik data 1 memperlihatkan bahwa petir terjadi pada jarak $50 \mathrm{~km}$ hal ini menjadikan bahwa lokasi data 1 yang didapatkan tidak valid karena berdasarkan perhitungan jarak dengan stasiun Unand hanya 7 $\mathrm{km}$. Hasil lokasi yang kita dapat berbeda dengan bentuk gelombang medan listrik mengindikasikan terjadinya kesalahan dalam perekaman data yang bisa diakibatkan seperti tidak sinkronnya waktu komputer akibat terputusnya koneksi internet, perangkat lunak yang melakukan perekaman lambat merespon, dan delay yang terjadi pada perangkat perekaman.

Data 2 terletak jauh dari jangkauan dari geometri sistem hal ini dibuktikan dengan jarak antara stasiun dengan petir yang bertentangan seperti yang diperlihatkan pada gambar 12 . Berdasarkan data $\Delta t$ seharusnya petir terjadi berdekatan dengan stasiun Tabing namun hasil perhitungan lokasi petir berada dekat dengan stasiun Padang Pasir.

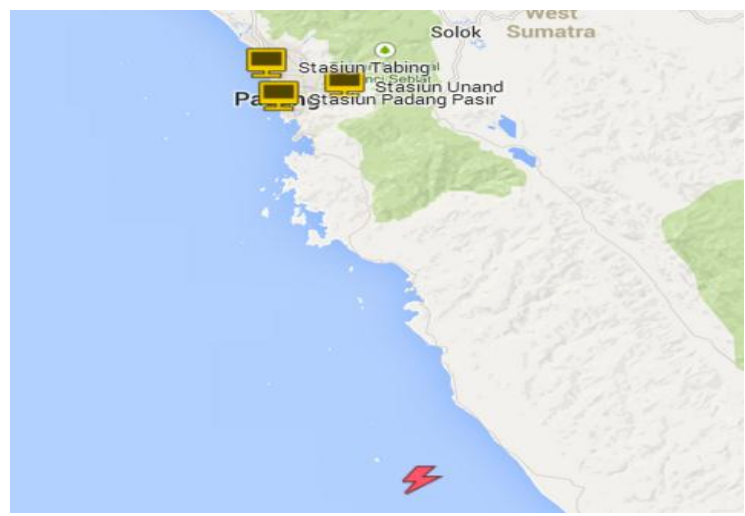

Gambar 12. Lokasi petir yang dihasilkan perhitungan pada data $2(14: 41: 50)$

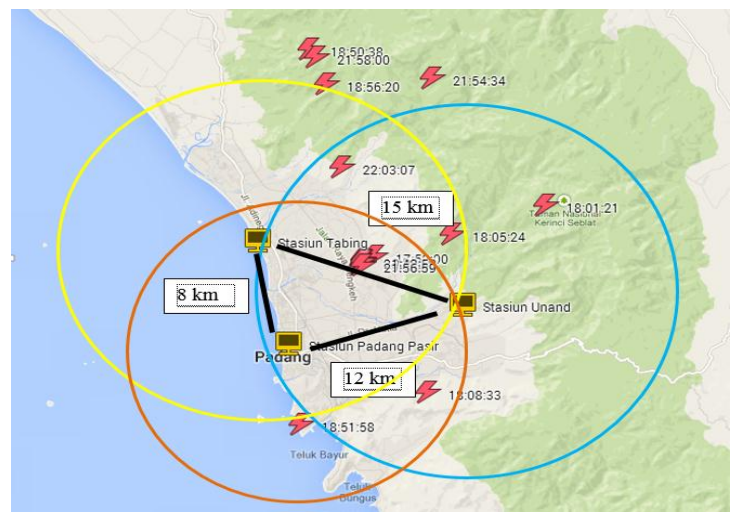

Gambar 13. Daerah Jangkauan Sistem deteksi petir
Berdasarkan teori kejadian petir yang dapat dihitung berada pada jarak radial antara sensor dengan sensor seperti yang terlihat pada gambar 13. Jarak antara sensor petir yang terjauh adalah $15 \mathrm{~km}$ yakni antara sensor Tabing dengan Unand sehingga jika petir terjadi melebihi jarak tersebut maka perhitungan menghasilkan lokasi yang salah. Dari bentuk gelombang medan listrik dapat diketahui bahwa pada data kedua ini petir terjadi pada jarak jauh dari $50 \mathrm{~km}$ yang dibuktikan dengan gambar 14.

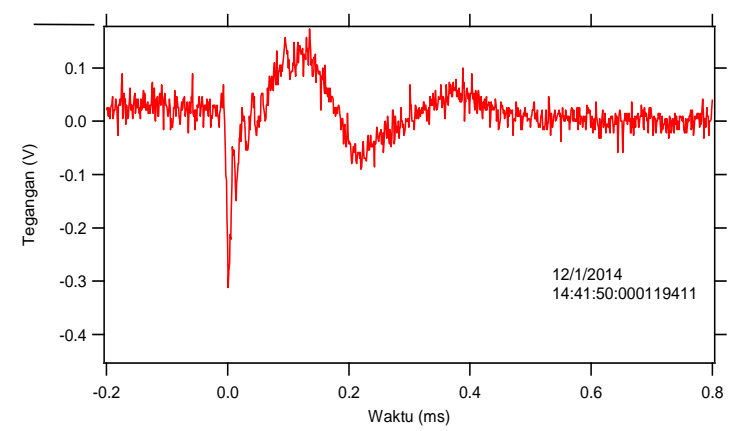

Gambar 14. Bentuk Gelombang Medan Listrik Petir pada Data 2(14:41:50)

Pada kasus seperti ini cara untuk mengatasinya adalah dengan penambahan stasiun atau memperbesar jarak antara sensor petir sehingga luas daerah jangkauannya semakin luas. Hal ini bisa dibuktikan dengan memindahkan stasiun 1 imajiner yang dipakai sebagai titik referensi nol untuk mendapatkan koordinat petir tersebut dimana dipakai titik referensi nol berada pada $\varphi=-0,5, \lambda=100,35$ sehingga lokasi petir yang dihitung oleh Program ToA berada pada koordinat $\varphi=$ $0,53370, \lambda=100,33129$ dan jarak petir pada masing-masing stasiun yakni dengan Stasiun Tabing 37,167 km, Stasiun Padang Pasir 44,604 $\mathrm{km}$, dan Stasiun Unand 44,621 km. Petir berada dekat dengan stasiun Tabing seperti yang lihat pada gambar 15 dan sesuai dengan nilai $\Delta t$ yang didapatkan. 


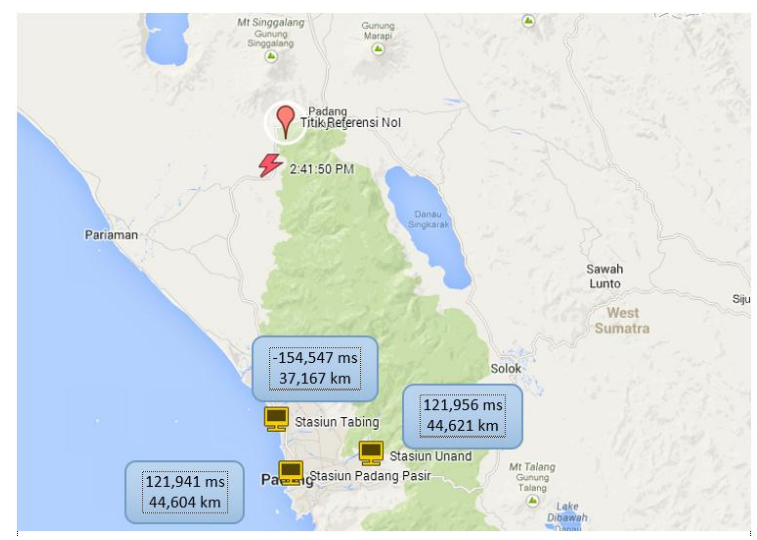

Gambar 15. Lokasi Petir Data 2(14:41:50)

Setelah Pemindahan Stasiun 1 Imajiner

\subsection{Penentuan Arus Puncak Petir}

Arus puncak petir adalah nilai arus tertinggi terhitung dari data petir. Arus puncak petir merupakan parameter petir yang penting dalam perencanaan proteksi peralatan elektrik. Dengan mengetahui berapa nilai arus tertinggi dari kejadian petir pada suatu lokasi maka akan meminimalisir kerugian akibat yang ditimbulkan oleh petir tersebut.

Dari 20 sampel data hanya 8 data yang dapat dihitung jaraknya dan sesuai dengan bentuk gelombangnya. Berdasarkan hal tersebut maka arus puncak yang kita cari pun terbatas pada ke 8 data tersebut. Maka data arus puncak petir yang terhitung dapat kita rangkum dalam tabel 3 . Dari tabel 3 didapatkan arus puncak petir yang terendah didapatkan bernilai -1,001 kA dan yang tertinggi didapatkan -22,661 kA.

Tabel 3. Nilai Arus Puncak petir

\begin{tabular}{c|ccccc} 
NO & WAKTU & $\begin{array}{c}\text { VD } \\
(\mathbf{M V})\end{array}$ & $\begin{array}{c}\text { D } \\
(\mathbf{K M})\end{array}$ & $\begin{array}{c}\text { EP } \\
(\mathbf{V} / \mathbf{M})\end{array}$ & $\begin{array}{c}\text { IP } \\
(\mathbf{K A})\end{array}$ \\
\hline $\mathbf{1}$ & $14: 42: 55$ & -1.781 & 7,518 & $-26,349$ & $-5,5072$ \\
$\mathbf{2}$ & $14: 48: 26$ & $-745,9$ & 7,561 & $-11,035$ & $-2,3198$ \\
$\mathbf{3}$ & $17: 59: 00$ & -1.184 & 7,029 & $-17,517$ & $-3,4231$ \\
$\mathbf{4}$ & $18: 01: 21$ & -1.168 & 9,521 & $-17,280$ & $-4,5742$ \\
$\mathbf{5}$ & $18: 08: 33$ & -2.046 & 7,089 & $-30,270$ & $-5,9654$ \\
$\mathbf{6}$ & $18: 51: 58$ & -3.837 & 14,359 & $-56,767$ & $-22,661$ \\
$\mathbf{7}$ & $19: 18: 46$ & $-323,5$ & 7,526 & $-4,786$ & $-1,001$ \\
$\mathbf{8}$ & $21: 42: 59$ & 462 & 7,609 & 6,835 & 1,4459 \\
\hline
\end{tabular}

Arus puncak petir berkaitan dengan nilai tegangan medan listrik $E p$ dan jarak dari sumber dengan sensor. Dari ke 8 data yang memiliki kesesuaian dalam bentuk gelombangnya dapat kita simpulkan bahwa pada jarak yang sama semakin besar Ep maka semakin besar pula Ip yang didapatkan.
Dari penelitian ini masih masih terdapat noise yang mengganggu dalam perekaman data. Sumber noise ini disebabkan dari sumber daya listrik yang dipakai dan sumber luar penghasil gelombang elektromagnetik seperti sinyal telepon selular. Pada penelitian selanjutnya difokuskan pada pengurangan noise-noise ini sehingga bentuk sinyal medan listrik petir yang didapatkan dapat dengan mudah dianalisa dengan sampling yang lebih banyak dari penelitian sebelumnya.

\section{KESIMPULAN}

1. Geometri sensor petir mempengaruhi keakuratan dalam penentuan lokasi dalam metode ToA LS.

2. Jumlah sensor dan jarak antar sensor mempengaruhi luas daerah yang lokasi petirnya dapat ditentukan.

3. Dari 20 data terdapat 8 data yang lokasinya sesuai dengan bentuk gelombang medan listrik.

4. Tidak sesuainya data dengan bentuk gelombang diakibatkan gagalnya sinkronisasi dan kesalahan perangkat lunak maupun perangkat keras.

5. Arus puncak petir yang terendah didapatkan bernilai $-1,001 \mathrm{kA}$ dan yang tertinggi didapatkan -22,661 kA.

\section{Ucapan Terima Kasih}

Terima kasih penulis ucapkan kepada Beasiswa Unggulan (www.beasiswaunggulan.go.id) atas biaya pendidikan magister selama tahun 2011-2013 dan Universitas Andalas yang memberi bantuan dana penelitian BOPTN, dengan kontrak No. 01/UN.6/PL/US2,S3/2014.

\section{DAFTAR PUSTAKA}

[1] Boonstra, Rudger. Validation of SAFIR/FLITS lightning detection system with railway-damage reports. Master Thesis. Royal Netherlands Meteorological Institute. (2008). 
[2] Zulkarnain Abdul-Malek, Aulia, Nouruddeen Bashir and Novizon. Lightning Location and Mapping System Using Time Difference of Arrival (TDoA) Technique, Practical Applications and Solutions Using LabVIEW ${ }^{\mathrm{Tm}}$ Software, Dr. Silviu Folea (Ed.), ISBN: 978-953-307-650-8, InTech. (2011).

[3] Uman, A. Martin. The Lightning Discharge. International Geophysics Series. Academic Press Inc. Orlando. (1987) .

[4] Geitz, C. William dan Jack Mcguiness. Application of Lightning Detection and Warning Systems within the Explosives and Blasting Environment. Volume III. Minutes of the Twenty-Fifth Explosives Safety Seminar Held in Anaheim, CA. (1992).

[5] Rakov, Vladimir dan Martin A. Uman. Lightning Physics and Effects. Cambridge University Press. New York. (2001).

[6] Wanke, Egon. A low cost Time of Arrival Lightning Detection and Lightning Location Network. Blitzortung.org. Germany. (2011).

[7] Finke,U dan O. Kreyer. Detect and Locate Lightning Events from Geostationary Satellite Observations. Report. Institute für Meteorologie und Klimatologie Universität Hannover. Germany. (2002).

[8] Cummins,K.L., E.A Bardo dkk. A combined TOA/MDF technology upgrade of the U.S National Lightning Detection Network. J. Geophys. Res., 103, 9035 9044. (1995).

[9] Lewis, E.A. Hyperbolic Direction Finding with Sferics of Translatic Origin. J. Geophys. Res, 65, 1879-1905. (1964).

[10] Koshak, William J,. R.J Solakiewicz. TOA Lightning Location Retrieval on Spherical and Oblate Spheroidal Earth Geometries. J.Atmos. Oceanic Technol, 187-199. (2001).

[11] Lin, Y. T., M. A. Uman, J A. Tiller R. D. Brantley, W. H. Beasley, E. P. Krider, dan C.D Weidman.Characterization of Lightning Return Stroke Electric and Magnetic Fields from Simultaneous Two Statiun Measurement, J. Geophys. Res., 84, 6307-634, doi:0.109/JC084iC0p06307 .(1979)
[12] Koshak, William J,. R.J Blakesle, dan J.C. Bailey, Data Retrieval Algorithm for Validating the Optical Transient Detector and the Lightning Imaging Sensor. J. Atmos Oceanic Technology.17, 279-297. (2000).

[13] Lenart, A.S. Solutions of Inverse Geodetic Problem in Navigational Applications. The International Journal on Marine Navigation and Safety of Sea Transportation. DOI:10.12716/1001.07.02 .13. (2013).

[14] Diendorfer, Gerhard. Lightning Location Systems. IX International Symposioum on Lightning Protection. Brazil. (2007).

[15] Koshak, William J, dan R.J.Solakiewicz.On the Retrieval of Lightning Radio Source from Time of Arrival Data. Journal of Geophysical Research 101 p 26,631-26,639. (Nov 27, 1996).

[16] Haddad, Michael A, Rakov dan Cummer. New Measurement of lightning electric fields in Florida: Waveform characteriscic, interaction with ionosfer, and peak current estimates. Journal of Geophysical Research 117 D10101. (2006).

\section{Biodata Penulis}

Dasrinal Tessal, ST : Lahir di Solok,10 Desember 1985. Menamatkan pendidikan S1 di Jurusan Teknik Elektro Universitas Andalas tahun 2010. Pada saat ini penulis sedang menyelesaikan pendidikan S2 pada institusi yang sama. 